\title{
MILITARY MAIL RADIO
}

\author{
Răduţ BÎLBîIE \\ bilbiie@yahoo.com
}

“NICOLAE BĂLCESCU” LAND FORCES ACADEMY, SIBIU, ROMANIA

\section{ABSTRACT}

Cultural and scientific personalities from the army, military experts and creators of the doctrine have collaborated with the radio from the beginnings of radiophony, the educational role of this new, persuasive communication channel being evident not only for Romania or the Romanian army but also for all the countries that had radiophony services. This happens in the context of the end of the crisis and the start of economic and social development, promoting culture, creating a solid class of peasants with a certain social status, in villages, together with the priest, teacher and gendarme, increasing of the number of subscriptions and development of the Romanian radiophony

The radio has been used as a means of persuasion of the population for the war effort through broadcasts intended for pre-military boys, then for the entire population or soldiers. Operational means of connecting military and their families, an effective tool in maintaining a good morale of the troops and a satisfactory state of mind of the population with relatives in theatres of operations, Poșta militară radio has proven effectiveness through millions of letters sent along its four years of existence.

\section{Keywords}

Poşta militară radio, Ora ostaşului, morale of the troops, Romanian Broadcasting Society, General Staff

\section{Introduction}

In early June 1940, by an agreement between the General Staff and the Romanian Radio Broadcasting Company, the broadcast of a radio show called Ora Ostaşului was decided starting with June 16, 1940, it being considered one of the best occasions of moral courage and recovery of the army and the nation, as noted in the instructions no. $6025 / B$, of July 18 , 1940, of the General Staff [1]. The broadcasting of Ora Ostaşului was daily (until December 31, 1941), then three times per week (Monday, Thursday and Saturday) until the end of the war.

Since August 2, 1942, Radio Bucharest and Radio Romania will transmit to Cronica războiului conducted by Romulus Seişanu, publicist. Radio Moldova will have in its programme, with effect from January 17, 1942, a Cronică Militară carried out by Lieutenant - Colonel Al. Constantin Mihăiescu. Other shows with military content, many made by journalists - reserved military working for the Department of Propaganda of the General Staff were: Ora Germaniei, Ora Italiei, Ora ostăşească germano-română, Ora ostăşească italo-română, De vorbă cu ostaşii, even Oră veselă a ostaşului, then, Ora armatei ca la Tănase, Ora răniţilor, Poşta militară radio and so on [2]. 


\section{Setting up a Radio Broadcast for the Military on the Front Lines}

The war began six months earlier when, in January 1942, the General Staff aiming to improve the communication between the military deployed in the areas of operations and their families, will initiate steps at the level of the leadership of the Radio Broadcasting Society for the establishment of a new show, to strengthen the morale of fighters through a fast and reliable connection with families, Poșta militară radio.

A note of January 16, 1942, of the General staff lists the contents of these proceedings: the current postal link with troops that are to the East of the Nistru and, in particular, in the Crimea, works very hard due to the atmospheric conditions that prevent air and auto links.

In order not to leave these troops the impression of isolation, Section 4 proposes the introduction of transmission of news from the families in the Homeland for the troops, noncommissioned officers and officers on the front, by the Romanian society of radio broadcasting stations, daily, within a broadcast called "Poşta Militară Radio".

Taking contact with the Romanian radio broadcasting Company, there have been established the followings:

1. Shows are also possible via Shortwave broadcast station.

2. They demanded Cavalry Corps and Mountainh Corps to report how the reception of the Radio Romania stations (long-wave) and Radio Bucharest (mediumwave), after which it will be decided if they can make showsto be broascast on these two wavelengths.

3. Time made available for shortwave is daily from 20:30-21:00. Subsequently, depending on he quantity of news for broadcast, the time can be increased up to one hour (20-21).

4. Transmission of news in front of the microphone through the announcers of the radio Broadcasting Company.
5. Sorting, and mail censorship in the form to be aired, will be made by the 4th Section, in which purpose please approve:

a. the establishment of an office within the Military Mail Inspectorate, composed of 4 reserve officers, with skills in this direction;

$b$. officer staff as provided in annex 1 for the employment of the office Poşta Militară Radio [3].

Seen four days later by the deputy commander of the General Staff, general N. Mazarini it will receive the resolution: to give orders in detail.

These will not delay to be issued, through an annex - note that indicates the appointed personnel: reserve Captain Carandino $J$. from C. 2 A. at present not deployed, reserve second lieutenant engineer Ioan Lăzărescu, at prezent deployed at Battalion 3 Roads Entrepreneurial Company, reserve lieutenant engineer Ivanovici, at present deployed at Regiment 2 Artillery, reserve second lieutenant. Demetrian Alex of Regiment 36 Infantry at present not deployed [4].

5 Mail Office from Section 4 of the General Staff transmitted by wire on February 2, 1942 to the major broadcasters, Avântul, Viforul, Decebal, Pietrosul, Detachment 1t.col. Tăutu, Gorun a message to inform that: To facilitate the postal private connection between the country and the troops at the east of the Bug, the General Staff in connection with thr Radio Broadcasting Company will start to broadcast news from the country from the spouses, children, relatives and acquaintances. So far, the news will be broadcast only from the country to the front.

IN 30 to 40 days, the General Staff and Radio Broadcasting Company hope to broadcast some good news from the front towards the country. Broadcasts will be made regularly, daily between 08:00 and $20: 30$ on short-wave, by the radio station, Radio Romania and Radio Bucharest.

In order to keep the secret the address of the person interested will be referred by naming only the branch he belons to.

Up to February 10, 1942, the shows will be broadcast for all large units at once. 
After this date, a day or more per week will be set for each large unit individually, so that identification could be done easier.

Please give orders as one or more stations to receive these radiograms that will be later broadcast to the troops. The above measures are to be transmitted immediately to the combat and combat support troops so as to be able to get direct radio broadcasts if they have radio sets [5].

Arrangements for promoting new communication solutions are reinforced by an encoded wire of the General Staff's deputy chief, General N. Mazarini. With effect from the date of receipt of this order, take measures that daily, until February 3, 1942, to listen to the radio journal at 14.00 and 20.00 hours of the radio stations, Radio Bucharest, Radio Romania and the Shortwave Station.

Communication concerning the Military Mail radio is transmitted.

Please report how you receive these broadcasts and the station that broadcasts the best show [6].

3. The Success of a Fast Communication Way and Raise of the Morale of Soldiers

The press release by the Radio Broadcasting Company by the address 29648 of January 29, 1942 , specified:

The General Staff of the Army brings to the public's attention the following:

Starting with February 3, 1942, the Military Mail radio will work for our brave soldiers fighting against Bolshevism, at the East of Bug.

The Mail will work for the time being, only from the country to the front.

News will be broadcast daily by the radio stations, Radio Romania, Radio Bucharest and the "shortwave" station, on a regular basis from 20.00 to 20:30 hours.

People who want to send news to their spouses, relatives or acquaintances from units located east of Bug, will address their letters to the military postal service of the General Staff of the Army.
The news will have to be written on an open postcard and will be drafted in the following way:

- who sends the news;

- lodging (village or town);

- who to be announced (officer, NCO, soldier),mentioning the branch that person belongs to and the military post office where he can be found;

- what kind of news is sent, for example:

"Mrs. Maria Ionescu, Albesti, Ilfov announces her husband, Corporal Gheorghe Ionescu, gunner, military post office no. 1122 that, we're all healthy, we received the monthly aid. Radu is doing well at school".

The news will have to be drawn up as short as possible and will not include any indication of the military unit the addressed person is deployed in [7].

The communiqué was broadcast at $14.00,20.00$ and 22.00 hours by all the stations, starting with January 25, 1942, on a regular basis, every day until February 3, 1942 [8].

As a consequence of the General Staff's address no 29095 of January 25, 1942 General Mazarini also told the Director of Radio Broadcasting Company that all the radio reception stations East of Bug are in a state of alarm and regular reception at 14.00, 20.00 and 22.00 hours daily, in order to receive the press release of the General Staff related to the military mail. Accordingly, we have the honour of asking you to make sure that, on a regular basis at the aforementioned hours the press release issued by the General Staff related to the military mail to be broadcast.

This release should end with the future opening signal of this broadcast [9].

The large units begin to report the degree of reception as early as January 25, thus Viforul (Cavalry Corps) wires: very good auditions on the radio Romania; weak on Radio Bucharest [10].

In the first issue, released on February 3, 1942, General of Division C. Pantazi, the Minister of National Defence, aired the following message: 


\section{SOLDIERS,}

By opening "RADIO MAIL" for you, brave fighters across the Nistru in the first letter I am sending to you, to tell you that we are proud of you and your deeds of arms.

Your bravery has longer ago crossed the borders of the Country and all our allies praise your deedss.

Our thoughts, all the time, are only for you and of you.

$B e$ and remain proud soldiers of H.M. THE KING AND RULER OF STATE MARSHAL ANTONESCU on the freed lands by your sacrifice for the Country and Cross. From now on your families will send to you brief news this way, but filled with love and exhortation.

\section{HEALTH AND SUCCESS; [11]}

The show was broadcast daily, on weekdays between 7.30-7.55 hours, on Saturday and Sunday, from 11.30-12.00 hours, initially on Radio Bucharest frequencies, then since February 1943 also on the shortwave station's frequencies, from 17.30-18.00 hours, and since September 1943 on Radio Romania and Radio Romanian Dacia, from $15.40 \mathrm{H}$ till $16.40 \mathrm{H}$. The Radioprograms indicate, since March 1944, an time interval of broadcast daily from 15.30 Hours [12].

\section{An Attempt to Communicate with the Prisoners from the Soviet Camps \\ On April 29, 1943, the wife of general} Brătescu, Christina Brătescu, the Red Cross delegate in Ankara, communicated the President of the Red Cross Society of Romania, in a statement, the disappointing conclusions of the meeting with Mr. Courvoisier, senior delegate of the International Committee of the Red Cross. The delegate suggested the organization of a hour of radio transmission of the messages sent by the families of our prisoners of war in the Soviet states [13] request at which the Bureau of Counterintelligence from section II provides that these broadcasts to be carried out only within the military radio mail, with the same character as those submitted by the soldiers on the front lines, without the use of any special mentionfor example that they are addressed to the prisoners. The Counterintelligence forbade any publication in connection with the decision to transmit messages for prisoners [14].

The events of August 23, lead to a chaotic situation, with encircled military units, with soldiers trying to come back towards the centre of the country, with a fluid and uncertain situation of troops in the area of operations. It will lead to an interruption of broadcasts, with negative consequences for the morale of the military, who may no longer have news from the folks at home [15].

Thus the General Staff, will reorganize since November 12, 1944 until the end of the war, daily sbroadcasts, from the country to the front, Office 5 of Section II being responsible [16].

The the Archive of the Romanian Radio Broadcasting Company a few pages of texts [17] are kept submitted by announcers. They were issued by Section IV of the General Staff as newsletters containing about 50 messages, grouped on branches: for infantry, for aviation services, followed by the Mail of the Wounded (Poșta Răniților).

Bulletin 1 of December 15, 1944, entitled Specific Radiogrames for the soldiers on the front, mentioned: Captain Cretu Constantin is announced by his father, Professor Nicolae Cretu from Ramnicu Valcea that the family are in good health and are waiting for him to return safely. Or: Second Lieutenant Dumitru Răducanu is asked by Miss Mia Ionescu in Bucharest to send news, being worried by his silence. She wishes him good health, along with his cousin Jeni. Or: Sergeant Dinţiu Dumitru announces Captain Străjescu Vasilescu or any others that might know him to write where he is located, to the following address: Orthopaedic Hospital Indoor Area No. 287 in Bucharest, 165 Traian St., where he is to be found being wounded [18]. 


\section{Conclusions}

The operative linking means of military and their families and effective tool in maintaining a good troops morale and a satisfactory state of mind of the population with relatives on the battlefields, Poşta militară radio proved its effectiveness through millions of letters sent during the four years of existence.
Although it was never possible to achieve a mail from the battlefields towards the country, this operation will be done experimentally, only after more than 50 years, when the Romanian radio Broadcasting Company will broadcast messages and thoughts of the soldiers' from the theaters of operations during the show Voci de acasă within the broadcasts from Iraq or Afghanistan.

\section{References}

1. Instructions of General staff no. $6025 / B$, of July 18, 1940, in the Romanian Military Archives (AMR), contemporary propaganda, folder 6, f. 9.

2. Eugen Denize, Propaganda comunista in Romania 1948-1953, ed, a-II a (Targoviste: Editura Cetatea de Scaun, 2011), ISBN: 978-606-537-076-0.

3. Note of January, 16 1942, signed by the Chief of the 4th Department, Col. C. Nestorescu, Director of the RRC, Vasile Ionescu Head of the Office 5, Lt.col. C. Zălaru. AMR, 5419, file 342 , p. 7.

4 Annex 1, Note on the proposed staff to be hired at the Office of "Radio Military Mail", AMR, 5419, file 342, p. 8.

5 Wire 29775 of January 31, 1942 of the 4th Section's head, col. C. Nestorescu, AMR, 5419 , file 342 , p. 3.

6 Wire 29093 of January 29, 1942, AMR, fond 5419, file 342, p. 4.

7 Memo, AMR, fond 5419, file 342, pp. 17-18.

8 AMR, fond 5419, file 342, p. 20.

9 Address by special courier, with Very urgent note, AMR, fond 5419, file 342, p. 5.

10 Wire SC 4359/H, AMR, fond 5419, file 342, p. 6

11 Message to the soldiers at the first broadcast, ibid. p. 2.

12 Collections Radiodifuziunea, 1942-1945.

13 AMR, fond MCG B1 Prisoners, file 568, pp. 90-93.

14 AMR, fond MCG B1 Prisoners, file 568, p. 218.

15 AMR, fond 5419, file 342, p. 6.

16 Ibidem.

17 Archive RRS, file 7, n.p.

18 Arhive RRS, file 7, n.p. 